\title{
Globalisation and Labour Utilisation in Nigeria: Evidence from the Construction Industry ${ }^{1}$
}

\author{
Edlyne E. Anugwom*
}

\begin{abstract}
This study examines the influence of globalisation on labour utilisation in $\mathrm{Ni}$ geria using the construction industry as a case study. It reveals that the era of globalisation has given rise to profound changes in the way labour is utilised, specifically in terms of employment patterns as well as the related issues of earnings, job security, unionisation etc. In effect, the way the worker is used by the firms in the industry is determined solely by the dictates of capitalism, i.e. the profit motive. The conclusion is that the consequences of globalisation have been unfavourable to the workers in the so-called 'semi-skilled' category. Thus, neo-liberal globalisation, contrary to the often-benevolent impacts attributed to it, has worsened rather than improved the situation of workers in the construction industry in Nigeria. This then calls attention to the need for inter alia a more focused regulation of the activities of Multinational Corporations (MNCs) and the enforcement of minimum ILO standards in member countries, especially in the developing world where the need to attract the all important foreign investment may override any other consideration.
\end{abstract}

\section{Résumé}

L'étude examine l'impact de la mondialisation sur l'utilisation de la main-d'œuvre au Nigeria avec comme exemple l'industrie de la construction. Elle révèle que la mondialisation a engendré de profonds changements sur la manière dont la main-d'œuvre est utilisée, en particulier en constances de recrutement, de rémunération, de sécurité de l'emploi, de syndicalisation, etc. En effet, la façon dont le travailleur est utilisé par l'entreprise est uniquement déterminée par les

* Department of Sociology/Anthropology, University of Nigeria, Nsukka, Nigeria. Email: Edlyneeze@yahoo.com 
principes du capitalisme, à savoir le souci du profit. La conclusion est que les conséquences de la mondialisation sont défavorables aux travailleurs, soi-disant, semi qualifiés. Ainsi, la mondialisation néolibérale, contrairement aux effets souvent bienveillants qu’on lui attribue, a détérioré la situation des travailleurs nigérians de l'industrie de la construction plutôt que de l'améliorer. C'est pourquoi il est nécessaire de porter plus d'attention à une réglementation plus ciblée des activités des Corporation multinationales et à une application des normes minimales du Bureau international du travail au sein des pays membres, particulièrement dans les pays en développement, où le besoin d'attirer les très importants investissements étrangers peut prévaloir sur toute autre considération.

\section{Introduction}

Globalisation, which has been seen in various manner as the continuous narrowing of the gap between nations of the world (see Held 1997; Mittelman 1995; Sakamoto 1994; Campenella 1993; Held and McDrew 1993; Griffin and Khan 1992; Reich 1991; Albrow and King 1990; Ohmae 1990; Hobsbawm 1990), can be perceived as the most resilient factor in today's world. It implies a drastic reduction of distance both in time and space. In other words, globalisation has greatly reduced the obstacles imposed by spatial reality on interactions between nations. Globalisation has thus occasioned a far-reaching assault on state frontiers and a reduction of the communication barriers between states. With this surging socioeconomic reality, there has been the spread of influences, goods and artefacts from one end of the world to another. But just like in most other development related phenomenon, globalisation has created some unequal partnerships between the developed and the developing world. In this sense, the developing world can be seen as more or less the receivers or clients of globalising trends powered or supplied from the developed world.

For Giddens (1990), globalisation implies the intensification of worldwide social relations which link distant localities in such a way that local happenings are shaped by events occurring many miles away. However, this definition gives the impression that globalisation is a balanced process of interchange or exchange between societies. Globalisation has been everything but a balanced process of interchange between the global South and North. In spite of the controversies that have trailed the concept ranging from its nature as a contested or paradoxical concept (see Geigher 1988; Cerny 1997) to its conceptualisation as a process occurring for ages now (Olurode 2003), globalisation can be clearly distinguished as a new dawn in the process of relationship and interchange between societies in the world. In other words, globalisation as now conceived signifies a new dimension in international relationship premised in reality on inequality between the South 
and the North. In the case of Africa, some Authers conceive it as a historical process repositioning Africa between marginalisation and globalisation (see Olurode 2003).

Thus, globalisation as now obtains impoverishes and marginalises Africa. A situation which Nyang'oro and Shaw (1998) see as the outcome of the absence of an African viewpoint in the initiation and implementation of the global change processes of structural adjustment programmes and democratisation and in different world trade agreements foisted on Africa. This entails that globalisation's new routes to Africa were through economic reform programmes and the second wave of democratisation in the continent. In this sense one agrees with the contention that structural adjustment and global integration are interdependent and mutually reinforcing (Aina 1997). Thus, for our purpose here we see the point of departure of globalisation in Nigeria as the mid-1980s with the introduction of the Structural Adjustment Programme (SAP). Therefore I subscribe to the contention that 'the economic restructuring project was, therefore, a major component of the globalisation process introduced into Africa in the form of structural economic reforms known variously as economic stabilization programmes, economic adjustment policies, economic reform programmes or structural adjustment programmes' (Onyeonoru 2003: 39). The SAP is apparently a well-researched issue that need not detain us here. Suffice it to say that it was an economic adjustment measure allowing for the triumph of neo-liberal monetarist economic policies. Prominent in the case of Nigeria were the dominance of market forces, the retreat of the state from economic management, trade liberalisation, currency devaluation, reduction of non-productive investments in the public sector, rationalisation of the work force in the public sector, privatisation and general economic liberalisation, among others. In summary, the SAP in the view of one of its staunchest advocates, Nigeria's former Finance Minister Chu Okongwu, 'combines a nexus of measures aimed at promoting economic efficiency and long term growth with stabilization policies designed to restore balance of payments equilibrium and price stability' (Okongwu 1987: 4). From the eventual introduction of the SAP in the mid-1980s until the present Nigeria has been the willing recipient of the different influences of globalisation ranging from economic policies to social values and lifestyles.

As Lee (1997) pointed out, globalisation has aroused much concern regarding its social repercussions. Fundamental to such concerns are the effects of globalisation on employment, income or wages and labour supply and utilisation. These concerns can be seen as crucial in countries with an underdeveloped economic base. The influence of globalisation on the labour 
sector can be seen as very prominent since the economic dimension of globalisation has been the most influential in government policy determination. In fact, the economic connotations of capitalism have led some writers to posit that globalisation is nothing short of the expansion of capitalist hegemony. Be that as it may, such globally propelled economic initiatives, as privatisation, liberalisation and commercialisation, have been instrumental in economic policies in Nigeria. These initiatives, which aim at restructuring and reshaping the economy, may have affected the dynamics of the labour market in the country. In this sense, labour market logic and labour utilisation may be affected by these policies.

Furthermore, the opening up of the economy to external forces on a free market principle may have spawned some enduring influences on the nature of labour utilisation in the country. This can be fully appreciated if it is recognised that while globalisation has meant the movement of finance, ideas and goods more easily across national boundaries, the mobility of labour has not improved likewise, especially in the case of the majority urban-based semi-skilled work force. The semi-skilled 'urban workers'constitute a good number of the workers in any major construction enterprise in Nigeria. These workers, while serving as easy source of labour for the industry, are incidentally marginal or vulnerable to economic processes within and beyond the industry. Thus, while skilled workers are relatively mobile in the global context, semi-skilled workers are largely immobile are and often locked into the various sectors of the economy where they find themselves. Hence, while labour mobility has improved a little for the highly skilled workers, semi-skilled labour has become even more immobile.

As a matter of fact, the International Confederation of Free Trade Unions (ICFTU 1999) see trade liberalisation as exacerbating developmental inequalities, environmental degradation, workers' exploitation and gender imbalances. Therefore, the large proportion of Nigeria's labour force which falls into this category may be confronted by labour realities determined by globalisation. It is on this basis that this study seeks to find out the influence of globalisation on labour utilisation in Nigeria with specific reference to the construction industry. The study should be seen as an attempt to add to the existing empirical literature on the relationship between globalisation and labour. It goes without saying that labour studies have become more infrequent in Africa in spite of the tremendous changes witnessed in the labour process on the continent, especially in the context of globalisation. Moreover, most empirical studies on the construction industry in Nigeria were carried out prior to the era of neo-liberal globalisation. Thus this study is an attempt to bridge this critical gap in labour studies in the country. 


\section{Globalisation and labour}

Globalistion can be seen as largely responsible for rising inequality among workers, especially in terms of wages. In this case, the wage differential between the highly skilled worker and the semi-skilled worker widens disproportionately to the advantage of the skilled worker. In the same vein, the mobility of the skilled worker rises across international boundaries while that of the semi-skilled worker remains almost stagnant. In other words, a skill premium becomes prevalent. Thus globalisation, according to Dawkins and Kenyon (2000), engenders inequality in earnings in many Organisation for Economic Co-operation and Development (OECD) countries. But this trend is not only a phenomenon confined to one socioeconomic or geographic bloc but a growing reality in most economies of the world (Freeman and Katz 1995; Freeman 1995; Johnson 1997; Bound and Johnson 1992; Davis 1992; Katz and Murphy 1992; Gottschalk and Smeeding 1997; Gottschalk 1997). However as some writers have tried to find out (Dawkins and Kenyons 2000 and Paul and Siegel 2000), a question remains whether the wage differential is really a product of globalisation or are some other factors in the environment, particularly technology, working in concert with globalisation.

In this case, it is important to point out that in general terms a reasonable level of the difference in incomes or earnings between the skilled and unskilled workers may be attributed to the impact of technological changes (Lawrence and Slaughter 1993; Krugman 1994). In other words, as more and more technologies are introduced into the work place, the unskilled worker becomes more and more disadvantaged. However, this technology impact cannot totally or adequately explain the existence of this situation, especially in developing countries where the level of technological development and adoption is low relative to the developed world. Apart from this, our investigation in the Nigerian construction firms indicates that the so-called semiskilled workers are those who operate the machines, use various tools and devices while the so-called skilled workers function mainly in administrative and supervisory capacities with the exception of a few engineers and technicians in the field. This situation is a product of the fact, as Adesina (2000) mentioned, that credentialism is still a big factor in labour classification in Nigeria. In such a situation, the possession of a skill without a backing certificate is hardly recognised.

However, what emerges from the above is that globalisation aided by technology breeds a disdain for semi-skilled and unskilled workers. This disdain may be conveyed in the way workers in these two important categories are treated in the global firms of nowadays. But this disdain voids labour standards and creates a situation whereby firms undermine the principle of 
fair labour practice. In this case, the driving force becomes purely economic and the firms may as well lose sight of their social obligations and responsibilities. But the question of the nature of labour utilisation goes beyond the social, and has economic implications for both the individual worker and society concerned. As Lee (1997) suspects, the disdain for labour standards might not be unconnected with the neo-liberal views that a smaller role for the state will enhance the efficiency of the market. And a good way of doing this or limiting the role of the state is through a religiously followed privatisation and liberalisation package. In fact, these privatisation and liberalisation notions have been the pivots of economic globalisation in the developing countries. State intervention is seen as a more or less distorting and limiting factor on the growth potentials of the market, which is held responsible for most economic malaise ranging from unemployment to poverty. So in line with this current orthodoxy, the developing economies literally threw open their economies and the government retreated from intervention. However, this has led neither to economic growth nor to a significant generation of employment.

In spite of this, the World Trade Organisation (WTO), while facilitating free trade is reluctant to be drawn into the debate on labour standards. In this light, the WTO has argued consistently that labour issues are not its concern (BBC News, 22 October 1999). However, the concern with enforcing fair labour standards is driven by two different motives between the developed and developing countries. While the developed countries are afraid of the impact of cheap imports from the developing countries (lower wages and loss of jobs) on labour, the developing countries are faced with cheap wages for labour in global terms and the deepening of poverty. The WTO argues that even if individual jobs are lost, free trade boosts national incomes and prosperity as a whole. The views of the WTO that falling wages and job cuts are the products of technological change is supported by the OECD which contends that imports from low wage countries account for only 10 to 20 percent of wage changes in developed countries (BBC News, Ibid.)

The era of globalisation may have led to brighter prospects for highly skilled workers in the developing countries generally. In this case, a number of such workers have migrated to countries where their labour fetches them a larger earning power measured by the standard of the reigning international currencies. This emigration has occurred in only a few fields where the emigrants have some comparative skill superiority over a majority of the hosts. This sort of emigration from Africa to Europe and America is very prominent in the area of sports. A good example of this type of emigration was well illustrated in the popular French national football team of the 1998 and 2006 World Cup finals where the team was built on a core of players of 
African descent or origin. But this form of labour migration has aroused the concern of the developed countries over globalisation. This concern borders on the fact that cheap labour from outside threatens employment for indigenes. It may also create a situation whereby cheaply produced goods using cheap labour from the developing countries will weaken the competitiveness of home industries or firms. Such concerns are not ill founded. In fact, recently a South African sports administrator opined that the influx of foreign football players from other African countries had lowered the wage demands of the indigenous players, although it has strengthened the league. In other words, even though the developed world may be the attraction of labour migrants, the above illustration shows that such a backlash from globalisation may not be limited to the developed countries only. Hence, the need to restore the dignity of all forms of labour and ensure compliance with labour standards may be a global task. In spite of this, the developing countries may be worse off. Apart from the deepening of poverty engendered by cheap labour, the local industry may stagnate and the enormous capital flight from these economies will eventually undermine any real growth. Based on the foregoing, I will now examine labour utilisation in the era of globalisation in the developing countries.

\section{Globalisation and labour utilisation in the developing world}

The impact of globalisation on labour can be seen as lying largely within the discourse on the social implications of globalisation and its key elements in Africa - the SAP, and subsequent economic liberalisation (couched largely in terms of the retreat of the state and privatisation, among others). In this case, quite a lot of work has been done on the social implications of the economic adjustment programmes (Bourguinon, de Melo and Morrison 1991; Dorosh and Sahn 1993; Watkins 1995; UNRISD 1995; etc.). In addition to the adjustment programme, African countries have now been cajoled by the Bretton Woods Institutions into joining the new orthodoxy of open market economics, economic liberalisation or what is called neo-liberalisation in Latin America as well as the over-crowded train of privatisation, often in the name of post-adjustment macroeconomic management. However, apart from the concern which these have raised over income, poverty and the general welfare of workers, little or no attention has been given to the link between globalisation and labour utilisation.

It might be instructive to point out at this juncture that globalisation did not start the inequality between the two classes of skilled and semi-skilled workers. In fact, Slaughter (1999) has traced this inequality in the case of the United States and a number of European countries to the 1970s. In spite of this, the basic point is that the advent of globalisation may have further 
widened this gap and created more fundamental social inequality, particularly in the developing countries where the educational difference between these two classes of workers is often gaping. It is obvious that skill is mostly a product of education or prior learning, training and experience so those who are not really educated are hardly considered as skilled by developing countries standard.

The concern with the impact of globalisation on the utilisation of labour in developing countries can be seen as significant in the sense that it addresses a key element informing the formation of the International Labour Organisation (ILO). This element is the social justice or humanitarian concern over the conditions of labour. In this case, the ILO tries to achieve worldwide labour conditions devoid of hardship and privation. When this concern is married to the need to eliminate the negative cross-border externalities in countries failing to observe humane labour conditions, it becomes very necessary to continually interrogate the impact of globalisation on labour conditions. Since globalisation is all about narrowing and eliminating socioeconomic boundaries among nations, it seems logical to expect that global labour conditions and standards might be the norm. But in developing nations, it would appear that as globalisation ushers in an onslaught of foreign or international competitors on the local scene, the labour conditions are left entirely to the vagaries of the workers and the dictates of these international employers.

The main question then has to deal with the apparent wanton disregard of the ILO standards long adopted by member nations. Whilst these international or multinational employers have neglected these standards in order to maximise profits, the developing countries, including Nigeria, have been hard put to really enforce these standards. The reason, apart from the apparent political motive to be accepted as a free country (democratic and liberal), is the need to abide by the current economic vogue of liberalisation and openness. Moreover, these firms are seen as rendering essential services especially in the technical sectors and boosting employment in spite of the conditions under which workers in such firms work. The firms engaged in unfair labour practices and disregard of standards are basically driven by profit. In other words, they do not agree with the submission of Freeman (1995) that there is neither conceptual nor empirical proof to show that a higher labour standard is synonymous with higher labour costs. Therefore, for these firms the name of the game is cutting costs.

It may be interesting to point out that the concern with child labour in the developing nations even though well-founded often reduces the significance of other adverse conditions of labour which border on excessive hardship and privation. Therefore, the impact of globalisation goes beyond debates on 
its effects on child labour and includes the labour conditions either engendered or perpetuated by globalisation. This seeming disregard of labour standards in the developing countries in the last two decades calls attention to the need for a more result-oriented approach to the problem. As Lee (1997) shows, the opinion of some developing nations that it may be time to get tough with violators of labour standards is in order. The mere use of moral persuasion and voluntary compliance may not suffice. There may be a need for the international community to evolve more productive mechanisms for enforcing labour standards and ensuring the humane and fair utilisation of labour in spite of the skill content. This is really important, since the cognition that the economic position of the developing countries and their desire to join the train of the developed nations weaken their ability to really enforce any standard on foreign or international competitors who see themselves as involved in an economic rescue mission.

\section{Globalisation and labour utilisation in Nigeria}

The expression 'labour' as used here may more appropriately refer to the working population. The fate of the labour class in Nigeria has been the focus of externally sponsored economic initiatives since the mid-1980s. Adesina (1994) argues strongly that the adjustment programme in the country introduced in 1986 and which took its toll on Nigerian workers was based on a fallacy that sees the average African worker as an over-paid and pampered worker. According to him, this apparent falsehood was one engendering force behind the introduction of the programme. On a similar note, Anugwom (2000) has seen the wrong conception of the reality of the African worker by external agents as originating from the backward sloping supply curve of African workers made popular by colonially inspired literature of the 1960s and 1970s (see for instance Arrighi and Saul 1973). This notion argues that the African worker is one of the least productive in the world and labour supply in Africa is inclined towards reduction as the wages increase. In fact, it states that beyond a particular wage level, Africans will stop submitting themselves to labour but concentrate on enjoying what has been earned. This thinking subsequently informed the colonial attitude to Nigerian workers and was carried over to the post-colonial period.

It might be helpful to point out that the adjustment programme marked a very significant impact of globalisation in Nigeria. As has been well-documented (Adesina 1994; Anugwom and Anugwom 2000) the programme was a massive package of macroeconomic panaceas from the Bretton Woods Institutions for the ailing Nigerian economy. However, the adoption of this panacea has not helped the economy of the country in any significant measure. Hence, it might be in order to question the basic premise underlying the 
adjustment programme and subsequent post-adjustment economic policies in the whole of the continent. This is especially the case when it is remembered that even though more than thirty African countries embarked on various forms of the adjustment programme, Gross Domestic Product (GDP) stagnated in sub-Saharan Africa and per capita consumption fell in twentythree out of forty-one African countries during the same period (Demery and Squire 1996). It is crucial to emphasise that the effect of the adjustment on the labour sector was not totally unforeseen. As a matter of fact, the adjustment programme aimed at a reform of the labour sector in Nigeria. Thus, the World Bank (1994) saw this as central to the implementation of the programme. This effort to make the labour market flexible created unmitigated wage failures and long-lasting unemployment and can be seen as the nucleus of the problems of labour today (Anugwom 2001). Even the romance with the so-called post-adjustment economic measures today has been nothing short of the same macroeconomic policies, namely trade liberalisation, floating exchange value (market driven), privatisation and commercialisation, government withdrawal from social provisioning, decreased public sector spending and investment (retrenchment and rationalisation of the civil service) etc. As a matter of fact, the Nigerian government is currently toying with the idea of laying off about 33,000 public sector employees (Daily Independent 2006).

\section{The method of study}

In order to concretise the influence of globalisation on labour utilisation, we undertook a study of the construction sector in Nigeria using three firms as case studies. 'Construction' in this context refers specifically to the road construction (civil engineering) sector. The choice of the construction industry is a product of the fact that the major firms in this sector are multinational concerns and as Sawyerr (1999) has argued, the multinational or transnational companies have been crucial means for the expansion of globalisation. Therefore, the choice of the construction industry in a study of globalisation in Nigeria was borne out of the verifiable fact that almost all major players in the industry are multinational or foreign firms. Thus, one should expect to see the impact of globalisation on these firms as they are either expectedly run on the dictates of their headquarters or on some global template. We purposely chose three firms who have been part of the sector for at least five to ten years now. In order to take cognizance of the different sizes of firms in the sector, we first ranked the firms into three categories of large, medium and small scale (the three firms chosen can be seen as representative of the construction industry in the country in as much as they are 
typical of the three scales of operations in the industry) using such criteria as: length of involvement in the sector; national visibility; number of permanent workers; average number of contracts per annum and capacity (measured by possession of equipment, technical know-how and networking) since the national specification based on the stock capital and number of employees is ambiguous and the industry makes use of a higher percentage of temporary than permanent workers. Using these criteria, the following firms were selected:

\begin{tabular}{lll}
\hline Firm & Scale & Capacity* \\
\hline 1. Strabag Construction Ltd & Large & 8 points \\
2. Monier Construction Co. & Medium & 6 points \\
3. Enerco Nig. Ltd & Small & 4 points \\
\hline
\end{tabular}

* Evaluation of each firm on the criteria listed above under a total score of ten points

We studied the above three firms engaged in road construction in Nigeria using a combination of the interview and observation techniques. Given the predictable hostility of the firms to this type of study, we ruled out the use of the questionnaire and rather engaged the workers in informal but in-depth interviews. Also, the workers interviewed in each firm were purposely selected using the two major criteria of (a) accessibility and (b) level of rank or skill. In accessibility, the study targeted workers that could be approached and who were willing to talk under assurances of confidentiality. Because of the core objective of the research, the focus was on those workers described by the firms as semi-skilled. We must admit that our usage of the expression 'semi-skilled' is rather restricted. In this case, the major difference between workers in this category and those in the skilled category in the construction industry is formal education. In other words, these semiskilled workers are often more adept at using devices and equipment than some of the so-called skilled workers.

A total of forty-five workers were interviewed (that is fifteen workers from each firm). These interviews were recorded and later transcribed. All the interviews took place between August and November 2000. The study made use of six research assistants divided into three pairs. Each pair took charge of each firm and the interviews were conducted in the areas where the firms had considerable construction work. The interviews took place in Lagos, 
Abuja and Port Harcourt (Rivers State). In addition to the workers, three management staff of each firm were interviewed in order to achieve some form of balance in opinion and establish validity. Prior to the fieldwork, the research assistants who are graduate students of the University of Nigeria were trained for two weeks regarding the purpose of the study, instrument administration, translation and interview skills, etc. It is from the result of the interviews and the recorded observation of the researchers that the following discussion was drawn.

\section{Globalisation and labour utilisation in the Nigerian construction industry}

The findings of our study reveal the following effects of globalisation on labour utilisation in Nigeria: the re-emergence of casual labour, short-term employment, poor earnings, global control of the economy and de-unionisation of workers. These findings are detailed below:

\section{The re-emergence of casual labour}

The construction firms, as our study revealed, rely enormously on the use of casual labour. Casual labour used to be popular in Nigeria during the colonial era and a few years after independence but declined since the mid1970s except in cases of people who are basically illiterates and did not spend more than the first six years in formal schooling. Moreover, such people are usually located in the informal sector of the economy. But in these firms it is casual labour with a difference. Most of the people engaged in this sort of work are school certificate and even diploma holders. They are employed in such capacities as clerical assistants, messengers, road surveyors, drivers, etc. The casual workers are ideally daily-paid workers but in these firms, with the exception of one of them, the casual workers are paid at the whim of the firm.

One of the casual workers who spoke to us in one of the firms said he was an unemployed diploma holder in Marketing before joining the firm. According to him, 'I had to join this company after being without a job for four years. I'm just trying to manage, at least I can go out every morning like other people'. On further probes, he revealed that he was motivated by the need to see if he could save money and pursue a university degree in Business Administration. Another youth in his twenties joined the construction firm immediately after his secondary School Certificate training. Poverty, according to him, could not allow his family to train him up to university level in spite of the fact that he possessed the qualification needed for university admission in Nigeria. 
What emerged clearly from our study was that only about 10 percent of those occupying casual labour positions in these firms are qualified by virtue of their lack of education and/or experience to be in such positions. The others were induced into the work by poverty, unemployment and frustration. This is especially where the social hardship caused by the economic liberalisation programmes has become enduring in Nigeria. The hardship envisaged at the onset of the adjustment programme was supposed to be for a very short period but as the UNRISD (1995) study has shown such was not the case. In Nigeria, the adjustment created a burgeoning urban unemployment population and exacerbated poverty (Anugwom 2001; Bafyau 1992; Adesina 1994). The adjustment programme really fostered the need for countries to deregulate the labour market. In fact, this was an important policy thrust of the economic liberalisation in Nigeria where reforms of the public sector hinged on work force rationalisation and the restructuring of the sector (Onah 2000). This was a euphemism for retrenchment and a mass purge in the civil service. This policy led to the unpopular retrenchment or labour rationalisation exercises between 1986 and the early 1990s and which continues in different shapes to date (for instance, the so-called monetisation of civil servants allowance which has led to the disengagement of lot of support staff in the public sector). Therefore, even now, the emphasis on privatisation and a declining socioeconomic role for government has meant continuous retrenchment or labour rationalisation for all three tiers of the government. The only difference today is that such retrenchment is effected in small doses and is without the publicity of the previous years. This is understandable in the context of the current democratic spirit and the need of the ruling party to perpetuate the nice guy image. All the same, more people are daily thrown onto the unemployment market and those with any form of employment strive to hang on. However, the casualisation of labour in the period of globalisation may not be by any means a developing world reality only. As has been reported by Kennedy (1998) and Lavalette and Kennedy (1996), the abolition of the National Dock Labour Scheme in Britain in 1989 has led to the re-emergence of casualised, insecure and stressful work condition in the industry. This situation is linked by Kennedy to the reemergence of the commodification of labour which globalisation has produced.

\section{Short-term or temporary employment}

This type of employment in the construction industry in Nigeria is closely related to casual employment. However, this form of employment is relatively better in the sense that it enjoys a higher status than casual employment in the rating of the firms studied. But just like casual employment, the 
workers employed here have no job security. They are usually employed for the duration of a particular contract or job. But they may be dismissed any time the firms want to do so through one of the managers or site supervisors. The irony of the whole situation is that the firms recruit more than two-thirds of their work force from this category of workers. As our investigations revealed, in each project site there are usually less than ten or at most fifteen permanent staff of the firm while the rest are the short-term or casual employees. Workers in this category are seen usually as semi-skilled (using the rationale of credentialism which is very popular in Nigeria) by the firms in spite of the fact that they are engaged in jobs requiring a considerable amount of sometimes complex skills.

Again our interviews with some of the workers in this category show that workers in short-term employment are usually those who have prior experience of having worked in such or similar capacities with construction firms. This may explain why they are also paid more than the casual workers. However, the workers here on the average possess quite considerable skills in the construction sector. This is really a source of worry since one would have expected such workers to form the bulk of the regular or permanent work force of the firms. Again, most of the workers in this category are relatively older people who have been around for some time. One of our respondents in the small-scale firm, a man in his late fifties, informed us that he has been engaged in that occupation for the last twenty years. In his own words, 'I have worked with at least five of the biggest construction companies in this country, starting from Julius Berger, Dantata, RCC ... I mean and others'. Based on this information we sought to find out the reason for the high mobility on his part. He answered, 'my brother when the white man asks you to go, you go or when the construction finish you have to go'. But we went further to inquire if his mobility was a result of his lack of skill but he retorted, 'look if I have the machinery, I can build a road. What is there'?

This notwithstanding, we found out that these workers are usually aware of the short-term nature of their employment. In fact, a middle-aged operator of an earth-moving machine informed us that they are employed mostly for the duration of a specific contract. Therefore, with the expiration or conclusion of the contract they are disengaged. Asked why they submit to this type of employment, he argued, 'it's almost the same in all other construction companies in the country, unless you are very lucky or you want to go outside and find another job but some of us cannot. I for example cannot at this age begin to learn a new trade or occupation, this is the only thing I do well'. Obviously, the firms are capitalising on the structure of the economy and the locked-in nature of the skills of these workers to exploit them. 


\section{Poor earnings}

The inhuman utilisation of labour is closely related to the whole issue of income distribution. Those who are exploitatively utilised, as we conceive of it in this paper, are usually marginal to the labour process, underpaid and insecure. In this position, they are exempted from whatever effort is made towards income redistribution. It is beyond argument to state that income distribution is cognisant of labour market status (Rogers and van de Hoeven 1995; Lachaud 1994). In this case those who occupy perceived lower labour market status and whose incomes are low are usually the core target of well-planned redistribution efforts. But this can be hampered when such workers are marginal to the whole labour process. In such a case, a culture of very low income or earning is perpetuated and the workers are impoverished. This situation aptly captures the plight of a majority of workers in the construction industry in Nigeria.

It may actually be inappropriate to label what these workers are paid as wages or salaries. The workers are paid a pittance in comparison with their exertions. Even what Strabag, which is the best paying of the three firms, pays can still be labelled a pittance since it is grossly inadequate vis-à-vis the economic realities facing the workers. It is important to point out that unfair labour standards or the exploitative utilisation of labour the unavoidable outcome of poverty and underdevelopment does not correspond to the real situation. In fact, the empirical evidence indicates that the exploitative use of labour and a gross neglect of international labour standards especially in some industries like construction perpetuates poverty and is a product of the premeditated intention of maximising profit. Therefore, labour exploitation in the form of irregular or temporary employment, job insecurity, inadequate and irregular wages etc., exacerbates poverty and militates against the growth of the economy.

In addition to the very poor pay, the workers are regularly owed money beyond a reasonable pay day. In fact, in one firm, the workers claimed they had not been paid for close to four months. We found out that on the average the workers are paid about the equivalent of between sixty dollars and hundred dollars a month as the total take home pay. This pay is grossly inconsiderate of the prevailing economic situation in the country, since the worker can hardly live on such a stipend. As a matter of curiosity, we asked a man who works in the road-surveying unit of one of the firms how he copes with such a sum of money monthly. According to him, his wife also helps in the up-keep of the family since she sells petty goods in the market in his village. He had been forced to leave his wife in the village about 500 kilometres away. We found out that this was a normal practice imposed by economic 
realities on most of the workers with families. The idea is for the family to manage to eke out a living out of farming, trading, and other informal economic activities in the village or another location, preferably a semi-rural environment where the cost of living is considered relatively cheap while the man goes to work and sends home money periodically.

One tool open to workers to redress grievances is collective efforts, for instance, the trade union. But as one of our respondents argued, these construction firms seriously frown at unionisation and those who attempt any serious workers' association are most times quietly eased out. There are however exceptions but mainly among the so-called skilled workers. In fact, unionisation among these workers is difficult considering the nature of their employment (we will look at this later). However, the sad part of this employment scenario is that as mentioned elsewhere a lot of these so-called semi-skilled workers are employed in really high skilled positions as machine operators, mappers, surveyors etc. Apart from this, these workers are not paid on weekly or daily basis but have most times accumulation of unpaid earnings running into months. As one of respondents in the middle scale firm indicated, 'paying salaries here is at the determination of the big men. They pay us sometimes once in three months, so that every time, you are owed arrears of salaries. My brother, it is a hard life'. This situation is worsened with the payment of low wages.

The wage level is really deplorable given the fact that the official minimum wage in Nigeria currently ranges from about forty dollars a month (for the least paid state employees) to about fifty-five dollars a month (for federal employers) (using the street exchange value of the dollar to the Naira as at May 2006). Thus, the official take home earnings of the least paid unskilled public sector worker can be pegged at a minimum of between one hundred and one hundred and fifty dollars. And the equivalent of some of these workers, i.e. semi-skilled civil servants, earn as much as three hundred dollars a month in the public sector and even much higher in some other sectors of the organised private sector, for instance, the oil industry. Even though one of the firms is better in terms of wages, there is all the same no significant difference in their treatment of workers in this regard as our investigations revealed.

Because of the cost-saving nature of this labour practice, these firms end up recruiting only about a tenth of their entire work force as permanent employees. Even if one concedes to the argument that given the seasonal fluctuations in the fortunes of these firms (fluctuations arising from weather conditions and patronage), only less than half of the present number currently employed as temporary workers should be thus employed. Also, there is need for those recruited on a temporary basis to receive fair treatment. In 
other words, temporary employment should not be synonymous with social injustice, hardship and privation.

\section{The De-Unionisation of workers}

We discovered that over 70 percent of the workers in the construction industry are not active members of any industrial union. Apart from the animosity of the firms towards labour unionisation as confirmed by various sentiments of the workers interviewed, most of the workers argued that by the nature of their work they hardly find time for unionism. In the views of one of them, 'we don't have time for that. People are always out working till late and sometimes work far into the night depending on the schedule'.

The legislation in the country on unionisation, as apparent in the definition, empowers even those on temporary employment to form unions. As Yesufu (2000) and Otobo (2000) reveal, the latest trade union law on this matter known as the Trade Unions Act of 1973 sees trade union as the combination of workers, whether temporarily or permanently employed, targeted towards regulating the terms and conditions of their employment. The inability of the workers to come together largely because of terms of employment solely determined by the employers creates a critical lapse which is utilised by the firms studied in subjecting the workers to various forms of inhuman work situations. This is really where the central labour organisation, the Nigeria Labour Congress (NLC), should play a crucial role in sensitising workers marginal to the labour movement on their full rights and the benefits of unionisation. It goes without saying that the wrong use of labour militates against improving the quality of working life in Nigeria. As Oribabor (1993) argues, the trade union has a role to play in this regard. The efforts of the union can be guided by the desire to humanise working conditions and ensure the protection of the rights of the average worker. In the continued onslaught of globalisation and the changing work situations nowadays, workers generally stand to benefit more through concerted collective efforts rather than as individuals. The ILO, to which Nigeria belongs, guarantees the full rights of the worker under a democratic and humane working environment as well as the pivotal role of collective bargaining in the labour process.

\section{The foreign control of the economy}

The past two decades in Nigeria have witnessed a gradual but considerable control of the economy by foreign or multinational concerns representing largely external interests. Nowhere is this more pronounced than in the oil and civil construction industries where all the giant firms are multinational enterprises. Even where it appears as if Nigerians are in charge, they are nothing but the surrogates for the foreign owners. The firms we studied are 
characterised by this ownership pattern. In fact, in Strabag and Enerco, the entire crop of senior managers and engineers are non-nationals. This of course is not the result of the dearth of qualified Nigerians but the deliberate recruitment policy of the firms concerned. This more or less is the recruitment policy, as it were, of the other big players in the industry. While this may sound all right in the spirit of globalisation, it has created a situation where the firms have disregarded their corporate social responsibilities and perpetuated a culture of strictly business and profit. As a result, the inhuman treatment of workers can be partially explained by the ownership structure of the dominant firms in the industry concerned. These firms are multinational construction concerns.

In spite of this, Ahiakpor (1992) argues that multinationals perform very beneficial services in developing countries and are not given any credit for this. Ahiakpor, adopting a stand akin to the neo-liberal arguments of many African leaders and the World Bank, contends that the multinationals provide opportunity for people to earn higher incomes and consume improved quality goods and services in Africa and other developing countries. As obvious from the foregoing presentation, our concern is not with the provision of employment but the condition under which such employment takes place. Thus, while we agree that the corporations provide employment, we are worried about the nature of labour utilisation in such firms. As we found out in the case of the multi-national construction firms in Nigeria, the workers are underpaid and inhumanely utilised. Our thinking is that Ahiakpor has fallen into an uncritical desperate development syndrome in which anything goes so long as at the end of the day it will bring development to Africa. For one it cannot yield genuine or sustainable development and secondly, multinational corporations (MNCs) are not on any form of rescue mission, they are in it for the profit. Therefore, there is need for their activities to be closely regulated, as they impact on the people and the environment. Moreover, Nwosu (1997), while accepting the job creation role of MNCs, argues that their labour absorption capacity is low because they are interested in maximising profits. This mindset may partially explain why the firms we studied preferred to use over 60 percent of their work force on temporary or casual basis. Despite this, Nwosu concludes that the enormous debt burden, corruption and poverty currently existing in the developing countries do not really portray the MNCs as agents of economic development.

It is really important to emphasise that globalisation especially in the form of the adjustment programme, post-adjustment economic liberalisation (privatisation) etc., have further entrenched MNCs in many economies in the developing world including Nigeria. In a very passionate write-up, Akomolafe 
(1994) sees the MNCs in Africa as pursuing a slash-grab-and-run policy that militates against the development of the African continent. Incidentally, he illustrates this policy with the Nigerian case of the Ogonis and the Royal Shell oil company, known as the Shell Petroleum Development Company (SPDC) in Nigeria. However, while we sincerely do not want to join issues with Akomolafe on the controversial and complex Ogoni-Shell relationship (which has been made a human rights issue now in Nigeria), we agree that the MNCs have not given enough to either the environment or the work force, and that this is the picture we got from the construction industry in Nigeria.

\section{Refuting the facts: The management's response}

Efforts to interview the core management of the firms were unsuccessful, however the supervisors and managers who were interviewed ascribed the prevailing labour situation in the firms to official company policy. According to one site manager in Abuja, 'the company is run according to laid-down procedures that has nothing to do with what you or I think'. Pressed further, he replied, 'what you see here is synonymous to whatever you will see in any firm of this type in this country'. But another manager was frank enough to tell us that, 'the workers were not forced to work here, they can go if they like'. Reminded that the pay was not really anything to write home about, he retorted, 'well like I said the choice is that of the workers. If you don't like the pay you leave, it's as simple as that'. One site supervisor in Lagos was more forthcoming, while agreeing with most of the points we raised regarding unfair labour utilisation in the firm, he told us that most of the workers are veterans of the construction industry and can hardly fit in properly anywhere else. In his own words: 'Given the fact that there is almost little or no difference in the way the various companies deal with site workers; they (workers) have not much choice'.

The question that raises its head in this form of comment is whether the firms are engaged in some form of collaboration against the workers. The management denies this vehemently. Be that as it may, the firms obviously are taking advantage of the economic situation. In this sense, they are aware of the desperation of most of the workers to keep a job.

\section{Discussion and conclusions: The labour - globalisation inter- face}

It must, however, be pointed out that relating working conditions in indigenous enterprises to those in multinational ones even under globalisation would amount to the incomparable. This is because the multinational or foreign firms apart from sheer economics of scale advantages are usually mega- 
capital firms with astounding profit margins in different regions of the world where they operate. The above picture contrasts sharply with the struggling-to-survive stories of many indigenous enterprises in Nigeria. In fact the Manufacturers Association of Nigeria (MAN) 2006 Report paints a dismal picture of the sector. According to the Report, only ten percent of manufacturing companies in the country are still operational, and capacity utilisation has declined to 48.8 percent (The Guardian 2006). Incidentally the fate of the manufacturing industry in Nigeria is not anyhow much different from those of other indigenous economic concerns with the possible exception of the banking industry. Lee (1997) captured the adverse effect of globalisation when he attributed the questioning of labour standards to the increasing globalisation of the economy. According to him, this has raised the priority accorded the promotion of international competitiveness in the rhetoric of public policy. A common view is that heightened international competition as a result of globalisation increases pressures to cut costs, including labour costs, and to achieve greater flexibility in the production system. Thus, governments keen to retain and attract foreign investments make concessions and look the other way while the workers, especially in the face of the debilitating unemployment scenario in most developing countries, are more or less helpless.

The above sentiments succinctly capture the case of Nigeria. Since the advent of the long awaited democracy, the government has gone all out to attract foreign investment in all forms. In fact, a good reflection of the seriousness of the government in this regard is shown by the fact that there is a standing instruction (anonymous source - Nigeria Immigration Service; personal discussion, 11 January 2005) from the Presidency for expediting entry visa requests by foreigners. This coupled with various economic trips abroad by government personnel have yielded results in almost all viable sectors of the economy as the foreign influence has become almost over-bearing. This is particularly the case in the construction industry where the technical nature of the work has made foreign involvement $a b$ initio inevitable.

While we agree with the fact that there has always been foreign involvement in the Nigerian construction industry right from the onset, obviously because of underdevelopment in the early years of independence, such original big players like Brown Boveri, Reynolds Construction Company, RGC, Guffanti, Julius Berger, Monier Construction Company etc., have been joined by other big players hitherto uninterested in Nigeria, and a plethora of middle scale international firms. This influx as it were has been since the late 1980s. The overwhelming presence of these MNCs is especially significant in the oil sector too. Apart from an increase in number, there has been a larger scope of operations for these firms in the last decade. This has created a 
predictable impact on indigenous firms. In other words, the foreign or international firms have blossomed and taken over, with a resultant competition among them in the Nigerian market. A good illustration of the phenomenal growth of these firms can be given with the case of Strabag Constrution Company. This firm, prior to the 1990s, had a very small stake in the Nigerian construction industry. But since the 1990s, Strabag, using a combination of technical expertise and political patronage and of course the liberalisation of the economy has grown to be one of the biggest competitors in the Nigerian market. Another case is the increasing involvement of Lebanese and Israeli firms in the construction industry in the country (for instance Enerco and HFP). Thus, the era of globalisation has witnessed a tremendous growth in MNCs in the construction industry with various implications for the economy of Nigeria.

Therefore, the adverse utilisation of labour, as we found out was the case in this sector, affects other situations of the workers involved. Hence, when the firms are led by profit motive to exploitatively utilise labour, under the pretext that such labour is of the semi-skilled type, then it is obvious that such workers will face declining earnings and poverty. The emergence of this situation even in the present times is indeed worrisome. This is more so when we take cognisance of the fact that the extant literature reveals a continuous inequality of income or earnings over the years in Nigeria (Aigbokhan 1997; World Bank 1996). Perhaps it is instructive to point out that the working conditions of the construction workers were not significantly better in the pre-globalisation era. But while this is true, it may be crucial to underline the fact that globalisation as this study shows has entailed a further increase in both the intensity and scope of negative labour practices. The increase in construction activities in Nigeria and the inflow of finance into the sector have meant the utilisation of a great number of workers while unfortunately not allowing the improved fortunes in the finances of the firms to impact on the workers. But equally significant is that the apparent failure of globalisation to improve the situation of workers in the construction industry contradicts the rosy picture of the influence of globalisation often painted by its advocates.

It may sound too general to conclude here that neo-liberal globalisation has led to a deterioration in workers' income and working situation in $\mathrm{Ni}$ geria. However, Onyeonoru (2003) arrived at very much the same conclusion in an impressive study of globalisation and industrial performance in Nigeria. Specifically, he links globalisation to tendencies towards de-industrialisation in Nigeria. As a matter of fact, a recent MAN Report (2006) sees economic reforms in the last couple of years in Nigeria as doing more harm than good and severely cutting jobs and number of operational enterprises in 
the country (The Guardian 2006). Earlier on, Thomas (1995) argued that research on labour markets in Africa indicates dramatic falls in wages for workers as well as a shrinking labour force due to privatisation and deindustrialisation. It might also be crucial to mention once more that the inappropriate use of labour in Nigeria's construction industry may have predated globalisation. However, our basic finding is that globalisation heightened this practice and gave it some form of conventional seal. Evidence indicates that prior to the mid-1980s there were less than ten multinational construction firms in Nigeria. This number has more than doubled in the last decade (Federal Ministry of Works and Housing 2005, Abuja). Globalisation in this context should be understood in the sense of heightening global influences and values over the last one and half decades in Nigeria. Apart from the real exploitative usage of wage labour, this phenomenon has created a scenario whereby the national economy in Nigeria is mainly in foreign hands. This situation was recently portrayed in one of the soft sell magazines in Lagos, where an obscure Lebanese was reported as being behind the endless fuel scarcity in Nigeria.

The huge foreign presence in the economy is a direct product of the adjustment programme and other subsequent macro-economic liberalisation policies such as the privatisation policy. The privatisation exercise, which first began under the rubric of the adjustment programme, is currently being executed as part of the so-called post-adjustment macroeconomic policies by the government in Nigeria. As a matter of fact, apart from the energy and oil sectors, the government has virtually given up control of the other sectors of the economy. Privatisation as has been argued elsewhere is not synonymous with economic development and often negates the interest of the majority in an underdeveloped and corrupt economy (Okolie 2000). The demands of a speedy externally driven privatisation have created a situation where government has retreated from even social provisioning. As a result, the government's involvement in key social sectors has been declining over the years. For instance, in the area of housing, the government has carefully disengaged itself since the early 1990s by sponsoring a privatisation of housing and the provision of public sector workers housing through pooling together of workers' resources and a loans scheme in a largely comatose National Housing Fund (NHF) (Anugwom and Anugwom 2000; Anugwom 2000).

Given the above realities of globalisation, the African worker is far away from occupying the privileged aristocratic position articulated by Arrighi and Saul (1973) in their famous Labour Aristocracy Thesis. Again, the African worker nowadays is equally distant from being a partner in the expropriation of rural surplus as posited by Lipton (1977). Against the foregoing apparent 
truisms, I posit the notion of the instrumental use of labour in the era of globalisation. In this situation, as our study shows, the utility of labour and how the worker is used is strictly determined by the dictates of the profit motive. However, given the need for some form of coordination, collaboration and recognition of skill, the global capitalist gives some limited preference to a select few workers in the firm even though this does not transform these few workers into aristocrats of any form. This contention is well supported by the situation in the Nigerian construction industry.

Finally, the solution to the problem may be through the government overcoming its dread of the flight of foreign investment and desperate development syndrome. From this standpoint, the government should effectively regulate the activities of the MNCs, especially in the area of labour utilisation. It can work in concert with the ILO on this issue. Also, there is need for the NLC to step into the construction industry and help the workers in articulating their terms of employment. A good starting point might be in a redefinition of what constitutes semi-skilled labour and the enthronement of a wage level commensurate with the national average in the formal sector of the economy.

\section{Note}

1. This paper was first presented with the title 'Globalisation and Labour Utilization in the Developing Countries: The case of Nigeria' in the seminar series of the African Studies Centre (ASC), Leiden, the Netherlands on 12 April 2001. The author wishes to express gratitude to Piet Konings of the ASC for comments on the draft of the seminar version of the paper and the anonymous reviewers of Africa Development for helpful comments.

\section{References}

Adesina, J., 2000, 'Income Distribution and Inequality: Gender, labour market status and macro-economic policy’, African Sociological Review, 4 (1): 1-34

Adesina, J., 1994, Labour in the Explanation of an African Crisis, Dakar: CODESRIA.

Ahiakpor, J. C., 1992, 'Multinational Corporations in the Third World: Predators or allies in economic development', Religion and Liberty, Vol. 2, No. 5.

Aigbokhan, B. E., 1997, 'Poverty Alleviation in Nigeria: Some macroeconomic issues', in Poverty Alleviation in Nigeria: selected papers for the 1997 Annual Conference of the Nigerian Economic Society, Ibadan: NES.

Aina, T. A., 1997, Globalisation and Social Values in Africa: Issues and research directions. Dakar: CODESRIA.

Akomolafe, F., 1994, 'Respect and Solidarity', Paper presented at the Workshop on 'The Treasure of the Titanic: choices for a North-South movement of tomorrow’, Ghent, Belgium, 9 November. 
Albrow, M. and King, E. eds., 1990, Globalization, Knowledge and Society, London: Sage.

Anugwom, E. E., 2001, ‘Urban Poverty in Nigeria’, in E. Ezeani and N. Elekwa, eds., Issues in Urbanization and Urban Administration in Nigeria, Enugu: Jamoe Pub.

Anugwom, E. E., 2000, 'The Socio-Economic Implications of the National Housing Fund Scheme', Proceedings of the National Workshop on the Administration and Benefits of the National Housing Fund (Loan Scheme) for the Public Service of Nigeria, Abuja: Federal Mortgage Bank of Nigeria.

Anugwom, E. E and Anugwom, K. N, 2000, The Structural Adjustment Programme and Urban Poverty in South-Eastern Nigeria: a study of wage earners, A Research Report Prepared for CODESRIA, Dakar, Senegal.

Arrighi, G. and Saul, J. 1973, 'Socialism and Economic Development in Tropical Africa', in G. Arrighi and J. Saul, Essays on the Political Economy of Africa, New York: Monthly Review Press.

Bound, J. and Johnson, G. 1992, 'Changes in the Structure of Wages inn the 1980s: an evaluation of alternative explanations', American Economic Review: 371392.

Bourguinon, F., de Melo J. and Morrison, C. 1991, 'Poverty and Income Distribution during Adjustment: issues and evidence from the OECD Project', Mimeograph, Country Economics Department: World Bank.

Campanella, M. L., 1993, 'The Effects of Globalization and Turbulence on PolicyMaking Processes', Government and Opposition, Vol. 28, No. 2: 190-205.

Cerny, P., 1997, 'Paradoxes of the Competition State: the dynamics of political globalisation’, Governmnent and Opposition, Vol. 32, No.2: 251-276.

Daily Independent, 2006, 'Oshiomhole Berates FG over Plan to Sack 33,000 Workers', Thursday, 13 July:1.

Davis, S. J., 1992, 'Cross-Country Patterns of Changes in Relative Wages', in O. Blanchard and S. Fischer, eds., 1992 NBER Macroeconomic Annuals, Cambridge, Mass: MIT Press.

Demery, L. and L. Squire, 1996, 'Macroeconomic Adjustment and Poverty in Africa: an emerging picture’, The World Bank Research Observer, Vol. 11 No.1, February.

Dorosh, P. and E. Sahn, 1993, A General Equilibrium Analysis of the Effect of Macroeconomic Adjustment and Poverty in Africa, Ithaca: Cornell University Food and Nutrition Policy Programme.

Freeman, R. B., 1995, 'Are Your Wages Set in Beijing', Journal of Economic Perspectives, 9: 15-32.

Freeman, R. B., 1994, 'Comments', in Ronald Ehrenberg, ed., Labour Markets and Integrating National Economies, Washington, D.C: The Brookings Institute.

Freeman, R. B., and L. F. Katz, eds., 1995, Differences and Changes in Wage Structures, Chicago: University of Chicago Press and NBER.

Geigher, J., 1988, The Future of the International System, (Translated Version), London: Unwin Hyman. 
Giddens, A., 1990, The Consequences of Modernity, Cambridge: Polity Press.

Gottschalk, P., 1997, 'Policy Changes and Growing Earnings Inequality in the U.S and Six Other OECD Countries', in P. Gottschalk, B. Gustafsson and E. Palmer, eds., Changing Patterns of Economic Welfare: an international perspective, New York: Cambridge Press.

Gottschalk, P. and Timothy Smeeding, 1997, 'Cross-National Comparisons of Earning and Income Inequality’, Journal of Economic Literature, 35: 633-687. Held, D., 1997, ‘Democracy and Globalization’, Global Governance, 3: 251-267.

Held, D. and McGrew, A.. 1993, 'Globalization and the Liberal Democratic State', Government and Opposition, Vol. 28 No. 2: 261-288.

Hobsbawm, E., 1990, Nations and Nationalism Since 1780, Cambridge: Cambridge University Press.

Hopkins, A. G., 1979, 'The Lagos Strike of 1897: an exploration in Nigerian history', in R. Cohen et al., eds., Peasants and Proletariats: the struggles of Third World workers, London: Hutchinson.

International Confederation of Free Trade Unions (ICFTU), 1999, 'Seattle Conference Must Tackle Labour Standards’, Press Statement, 4 November.

Johnson, G., 1997, 'Changes in Earnings Equality: the role of shifts', Journal of Economic Perspectives, 11: 41-54.

Katz, L. F. and Murphy, K. M 1992, 'Changes in Relative Wages, 1963-1987: supply and demand factors', Quarterly Journal of Economics: 35-78.

Kennedy, P., 1998, 'Coming to Terms with Contemporary Capitalism: beyond the idealism of globalization and the capitalist ascendancy arguments', Sociological Research Online, Vol.3, No. 2, http://www.socresonline.org.uk/ socresonline/3/2/6.html.

Lachaud, J-P., 1994, The Labour Market in Africa, Geneva: International Institute for Labour Studies.

Lawrence, R. Z. and Slaughter, M. J. 1993, 'International Trade and U.S Wages: great sucking sound or small hiccup’, Brookings Papers on Economic Activity, 2:161-226.

Lavelette, M. and Kennedy, P. 1996, 'Casual Lives? The Social Effects of Work Casualization and the Lock-out on the Liverpool Docks’, Critical Social Policy, Vol. 16.

Lee, Eddy, 1997, 'Globalization and Labour Standards: a review of issues', International Labour Review, Vol.136 No. 2,http:www.ilo.org/public/English/ support/publ/revue/articles/lee97-2.htm.

Lipton, M., 1977, Why Poor People Stay Poor: urban bias in World development, London: Temple Smith.

Nwosu, N. I., 1997, 'Multinational Corporations and the Economy of Third World States', Scandinavian Journal of Development Alternatives and Area Studies, Vol. 16 No. 2, July.

Nyang'oro, J. E. and Shaw, T. M. 1998, 'The African State in the Global Economic Context', in L. A. Villalion and P. A. Huxtable, eds., African States at a Critical 
Juncture between Disintegration and Reconfiguration Colorado: Lynne Rienner Publisher.

Ohmae, K., 1990, The Borderless World, London: Collins.

Okolie, A., 2000, 'The Political Economy of Privatization of Public Enterprises in Nigeria: a study of the Niger Gas Co. Enugu', in E. Anugwom, V. Okeke, R. Asogwa and I. Obasi, eds., Social Sciences: issues and perspectives. Nsukka: Fulladu Publishers.

Okongwu, C., 1987, 'A Review and Appraisal of the Structural Adjustment Programme, July 1986 to July 1987’, Special Press Briefing, Lagos: Federal Government Printer.

Olurode, L., 2003, 'Gender, Globalisation and Marginalisation in Africa', Africa Development, Vol. XXVIII, No. 3 and 4: 67-88.

Onyeonoru, I., 2003, 'Globalisation and Industrial Performance in Nigeria', Africa Development, Vol. XXVIII, No. 3 and 4: 36-66.

Oribador, P. E., 1993, 'Towards Improving the Quality of Working Life in Nigeria: the Role of trade unions', Review of African Political Affairs, Vol. 7 No. 1 \& 2, July/ December.

Otobo, D., 2000, Industrial Relations: theory and controversies, Lagos: Malthouse.

Paul, C. M. and Siegel, D. 2000, The Impact of Technology, Trade and Outsourcing on Employment and Labour Composition, Research Paper 2000/10, Centre for Research on Globalization and Labour Market, University of Nottingham.

Reich, Robert, 1991, The Work of Nations, New York: Simon and Schuster.

Rodgers, G. and van der Hoeven, R., 1995, eds., Reducing Poverty Through Labour Market Policies (new approaches to poverty analysis and policy, vol. iii), Geneva: International Institute of Social Studies.

Rosenau, J., 1990, Turbulence in World Politics, London: Harvester.

Sawyerr, A., 1999, 'Globalisation and Social Sciences in Africa', African Sociological Review, 3 (1): 1-19.

Slaughter, M., 1999, 'What are the Results of Product-Price Studies and What can We Learn from Their Differences?', in R. Feenstra, ed., International Trade and Wages, London: National Bureau of Economic Research.

The Guardian, 2006, 'MAN Report Shows High Job Loss, Low Output', 1 June: 1 and 4.

Thomas, H., 1995, Globalisation and Third World Union, London: Zed Books.

World Bank, 1994, Nigeria, Structural Adjustment Program: policies, implementation and impact, Report No. 13053-UNI, West Africa Department, Country Operations Division, Washington, DC: World Bank.

Yesufu, T. M., 2000, The Human Factor in National Development: Nigeria, Ibadan: Spectrum Books. 